\title{
Pengaruh Penguasaan Kosakata dan Motivasi Belajar terhadap Kemampuan Menulis Karangan Narasi Bahasa Indonesia
}

\author{
Sutarya \\ Fakultas Pascasarjana, Universitas Indraprasta PGRI \\ Jalan Nangka No. 58 C/TB. Simatupang, Tanjung Barat, \\ Jakarta Selatan 12530 \\ ahmad.sutarya@gmail.com
}

\begin{abstract}
The purpose of this research is to find out 1) The influence of vocabulary mastery and learning motivation on the ability to write narrative essay Indonesian, 2) The influence of vocabulary mastery on the ability of writing narratives essay Indonesian, and 3) The influence of learning motivation on the ability to write a narrative essay Indonesian. The research method used surveys. The sample size is 108 students selected randomly from all students of SMP Negeri Tirtajaya District Karawang regency. The study was conducted from April 2018 to May 2018. Data collection was conducted with tests, questionnaires, and documentation. Data analysis using simple regression and multiple regression method. The statistical test used $\mathrm{T}$ test and $\mathrm{F}$ test. The results showed: 1) mastery of vocabulary and student learning motivation obtained correlation coefficient of 0.134 with determination coefficient of $36.5 \%$ with multiple regression analysis is as follows: regression $=106,901+0,163 \mathrm{X} 1-0,427 \mathrm{X} 2 . \mathrm{t}=2,359$ and $-2,943,2$ ) There is a significant influence simultaneously in Vocabulary Mastery and Motivation Learning toward the Ability to write Narrative Essay Indonesian class VIII students SMP Negeri in District Tirtajaya Karawang regency. This is evidenced by $\mathrm{Fh}=8,089$ and the value of Sig $=0.001$ less than 0.05, 3) There is a significant influence Vocabulary mastery of Writing Capability Writing Narrative Indonesian students class VIII SMP Negeri in District Tirtajaya Karawang regency. This is evidenced by the value of $\mathrm{Th}=2.359$ and the value of $\mathrm{Sig}=0.020$ less than $0.05,3$ ) There is a significant influence of learning motivation on the ability to write Narrative Indonesian students class VIII SMP Negeri in District Tirtajaya Karawang regency. This is evidenced by the value Th $=-2.943$, and the value of Sig $=0.004$ less than 0.05 .
\end{abstract}

Keywords: Vocabulary Mastery, Learning Motivation, Writing Ability Narrative Essay Indonesian

\begin{abstract}
Abstrak
Tujuan penelitian adalah untuk mengetahui 1) Pengaruh penguasaan kosakata dan motivasi belajar terhadap kemampuan menulis karangan narasi bahasa Indonesia, 2) Pengaruh penguasaan kosakata terhadap kemampuan menulis karangan narasi bahasa Indonesia, dan 3) Pengaruh motivasi belajar terhadap kemampuan menulis karangan narasi bahasa Indonesia. Metode penelitian yang digunakan adalah survei. Sampel berukuran 108 siswa yang dipilih secara random dari seluruh siswa SMP Negeri Kecamatan Tirtajaya kabupaten Karawang. Penelitian ini dilaksanakan pada bulan April 2018 sampai Mei 2018. Pengumpulan data dilakukan melalui tes, penyebaran angket, dan dokumentasi. Analisis data dilakukan melalui metode regresi sederhana dan regresi ganda. Uji statistik dipergunakan uji t dan uji F. Hasil penelitian menunjukkan: 1) penguasaan kosakata dan motivasi belajar siswa diperoleh koefisien korelasi sebesar 0,134 dengan koefisien determinasi sebesar 36,5\% dengan analisis regresi ganda adalah sebagai berikut : regresi $=106,901+0,163 \mathrm{X} 1-0,427 \mathrm{X} 2 . \mathrm{t}=2,359$ dan $-2,943,2)$ Terdapat pengaruh yang signifikan secara bersama-sama Penguasaan kosakata dan Motivasi Belajar terhadap Kemampuan Menulis Karangan Narasi Bahasa Indonesia peserta didik kelas VIII SMP Negeri di Kecamatan Tirtajaya Kabupaten Karawang. Hal ini dibuktikan dengan $\mathrm{Fh}=8,089$ dan nilai Sig $=0.001$ kurang dari 0,05, 3) Terdapat pengaruh yang signifikan Penguasaan kosakata terhadap Kemampuan Menulis Karangan Narasi Bahasa Indonesia peserta didik kelas VIII SMP Negeri di Kecamatan Tirtajaya Kabupaten Karawang. Hal ini dibuktikan dengan nilai th = 2,359 dan nilai
\end{abstract}


Sig $=0,020$ kurang dari $0,05,3)$ Terdapat pengaruh yang signifikan motivasi belajar terhadap Kemampuan Menulis Karangan Narasi Bahasa Indonesia peserta didik kelas VIII SMP Negeri di Kecamatan Tirtajaya Kabupaten Karawang. Hal ini dibuktikan dengan nilai th $=-2,943$, dan nilai Sig $=0,004$ kurang dari 0,05.

\section{PENDAHULUAN}

Bahasa merupakan salah satu bagian terpenting dalam kehidupan manusia. Dengan berbahasa, dapat terlihat sifat, kepribadian, dan kemampuan seseorang. Manusia adalah makhluk sosial, yakni makhluk yang saling memiliki sifat ketergantungan antara satu dengan yang lainnya. Ini lazim disebut dengan interaksi sosial. Agar interaksi sosial dapat berjalan dengan baik, maka diperlukan alat yang berfungsi menyampaikan maksud atau kehendak antara satu dengan yang lainnya. Komunikasi dapat berlangsung dengan baik jika pelaku komunikasi terampil berbahasa.

Bahasa sebagai alat komunikasi merupakan komponen utama dalam mengembangkan ilmu pengetahuan, teknologi, seni, maupun budaya. oleh karena itu, untuk mewujudkan tujuan tersebut dibutuhkan kemampuan berkomunikasi yang baik dan terarah, karena pada dasarnya belajar bahasa adalah belajar berkomunikasi. Pemelajaran bahasa Indonesia diarahkan untuk meningkatkan kemampuan siswa untuk berkomunikasi dalam bahasa Indonesia dengan baik dan benar, baik secara lisan maupun tulis, serta menumbuhkan apresiasi terhadap hasil kesastraan Indonesia. Akan tetapi, harus diakui pemelajaran bahasa Indonesia di sekolah belum berlangsung seperti yang diharapkan. Guru cenderung menggunakan model pemelajaran yang bercorak teoretis dan hafalan sehingga kegiatan pemelajaran berlangsung kaku, monoton, dan membosankan. Pemelajaran bahasa Indonesia belum mampu memberikan kondisi yang kondusif. Mata pelajaran Bahasa Indonesia belum mampu melekat pada diri siswa sebagai sesuatu kebutuhan, rasional, kognitif, emosional, dan afektif.

Kemampuan berbahasa yang dilakukan oleh manusia adalah kemampuan produktif dan kemampuan reseptif. Kemampuan ini dapat dilakukan dengan lisan dan tulisan. Kemampuan berbahasa lisan biasadisebut berbicara, sedangkan kemampuan berbahasa tulis sering disebut menulis. Kedua kemampuan ini bertujuan untuk mempermudah manusia dalam berkomunikasi antarsesama dengan predikat peranannnya sebagai makhluk sosial.

Guru mempunyai peranan yang penting dalam mewujudkan tercapainya tujuan pemelajaran. Seorang guru bukan hanya memberikan pengetahuan kepada siswa, namun guru harus mampu menciptakan kondisi dan situasi yang memungkinkan pemelajaran berlangsung secara aktif. Pemelajaran bahasa Indonesia harus berorientasi pada proses dan hasil yang maksimal. Oleh karena itu harus ada perbaikan untuk guru dalam memilih model pemelajaran, Model pemelajaran yang dipilih harus memberikan kesempatan kepada siswa untuk bertanya, bekerjasama antarsiswa, membentuk hubungan positif, mengembangkan rasa percaya diri, serta meningkatkan kemampuan akademik secara kelompok. Sehingga konsep yang diajarkan oleh guru akan mudah ditangkap dan dipahami oleh siswa sehingga tercapainya kualitas pemelajaran lebih baik. Pembelajaran 
bahasa terjadi pada konteks tertentu. Penafsiran konteks amat penting dalam teori ini. Bahasa, belajar dan mengajar pasti selalu dipandang dari suatu konteks, latar, dan latar belakang. Program pemelajaran bahasa mulai dengan kegiatan komunikasi lisan. Setelah anak menguasai keterampilan dalam aspek mendengar dan berbicara, barulah guru memulai kegiatan komunikasi tertulis. Bahasa mengalami proses perubahan yang tetap, seperti pembetukan kata baru untuk memenuhi tuntutan komunikasi, tekana sosial yang mengakibatkan perubahan terhadap berterimaan item pemakaian khusus dan konstruksi bahasa.

Perkembangan ilmu pengetahuan dan teknologi yang semakin pesat saat ini menuntut proses pemelajaran di sekolah harus menyesuaikan dan mengikuti perkembangan yang terjadi. Meningkatnya kualitas proses pemelajaran akan menentukan mutu pendidikan. Kendala yang sering dihadapi adalah bagaimana proses dan penggunaan media pemelajaran di dalam kelas. Karena kebanyakan dalam praktik selama ini, guru sangat minim dalam memanfaatkan media pemelajaran, sehingga guru masih menerapkan model pemelajaran secara konvensional.

Pemelajaran bukanlah sesuatu yang terjadi secara kebetulan, tetapi merupakan sesuatu proses yang direncanakan, dilaksanakan, dievaluasi, sehingga dapat mencapai tujuan yang diharapkan. Adanya perubahan paradigm pemelajaran yang semula berpusat pada siswa, menurut adanya perubahan-perubahan unsureunsur lain yang menunjang dalam proses belajar. Kualitas pemelajaran dapat dilihat dari aspek proses dan aspek hasil pemelajaran. Proses pemelajaran dianggap berhasil apabila selama kegiatan belajar mengajar siswa menunjukkan aktivitas belajar yang tinggi dan terlibat secara fisik dan mental. Hal ini ditunjukkan dengan adanya interaksi aktif dalam pemelajaran antara siswa dengan guru, maupun siswa dengan siswa lainnya, sedangkan aspek hasil ditunjukkan dengan adanya perubahan perilaku yang positif pada siswa dan prestasi belajar yang tinggi.

Dalam mengelola sebuah proses belajar mengajar, seorang guru dituntut untuk menguasai materi, mampu menentukan baik strategi pemelajaran maupun penggunaan media pemelajaran yang sesuai dengan kebutuhan para siswa. Guru tidak hanya cukup memberikan ceramah di depan kelas saja, karena hal ini menjadikan siswa cepat bosan. Kebosanan inilah yang akhirnya dapat melemahkan minat dan motivasi siswa dalam belajar. Dengan menggunakan media dan model pemelajaran, diharapkan terjadi proses pemelajaran yang aktif, inovatif, kreatif dan menyenangkan sehingga kebosanan dapat dihindari.

Pemelajaran bahasa dalam dunia pendidikan pun dapat dirasakan manfaatnya terutama dalam penyampaian mata pelajaran bahasa Indonesia. Pemelajaran bahasa yang bertujuan meningkatkan kemampuan berkomunikasi mencakup empat bidang keterampilan bahasa, yaitu menyimak, berbicara (keterampilan reseptif lisan dan tulisan), membaca, dan menulis (keterampilan produktif lisan dan tulisan). Kemampuan berbahasa Indonesia secara tertulis juga merupakan salah satu aspek kemampuan berbahasa yang perlu diajarkan kepada siswa secara serius karena pemelajaran menulis berkaitan dengan proses belajar untuk berpikir secara kreatif. Siswa dalam pemelajaran menulis akan lebih dituntut untuk terus menambah pengetahuannya, baik yang berkaitan dengan 
tema, isi karangan ataupun teknik penulisan yang baik. Dari empat keterampilan berbahasa itu, menulis merupakan keterampilan berbahasa yang paling kompleks karena keterampilan menulis sangat memerlukan keterampilan berbahasa lainnya agar tulisan yang diwujudkan dapat dipahami. Selain hanya itu, kemampuan ini tidak diperlukan pada saat siswa mengenyam pendidikan, melainkan juga dapat bermanfaat dalam kehidupan mereka ketika sudah hidup bermasyarakat. Berdasarkan hal tersebut, maka tidak heran jika kemampuan menulis sudah diajarkan semenjak siswa mengenyam pendidikan dari bangku SD sampai perguruan tinggi.

Pada hakekatnya menulis merupakan kegiatan menyusun atau mengorganisasikan buah pikiran, ide, atau gagasan dengan menggunakan rangkaian kalimat yang logis dan terpadu dalam bahasa tulis. Kemampuan menulis mencakup berbagai kemampuan, seperti kemampuan menggunakan unsur-unsur bahasa, kemampuan menggunakan bentuk karangan, menggunakan gaya bahasa dan kemampuan menggunakan ejaan. Kemampuan menulis bukanlah suatu kemampuan yang diwariskan sejak lahir. Kemampuan menulis merupakan keterampilan yang dikuasai melalui pemelajaran dan latihan yang dilakukan secara tekun dan rutin.

Namun, pemelajaran menulis sekarang ini kurang mendapatkan perhatian mendalam. Selama ini proses pemelajaran menulis di sekolah hanya mengandalkan hasil tanpa memberikan proses. Hal tersebut sesuai dengan pendapat Wahluyo (dalam Musrifah, 1999: 1) yang mengatakan bahwa pemelajaran bahasa Indonesia masih sering diberikan secara teoretis sehingga mengakibatkan penampilan berbahasa siswa kurang dan bahkan model evaluasi pemelajarannya pun bersifat teoretis. Hal tersebutlah yang menyebabkan rendahnya kemampuan siswa dalam keterampilan menulis. Salah satu kemampuan menulis yang mesti dikuasai siswa tingkat sekolah menengah pertama yakni kemampuan menulis narasi. Melalui tulisan narasi, siswa mampu mengungkapkan imajinasi, ide, kejadian/peristiwa dalam bentuk kisah/cerita yang menarik. Rangkaian kalimat dalam tulisan narasi mesti disusun semenarik mungkin agar jalinan cerita yang dibangun semakin terasa hidup. Selain itu, kemampuan berbahasa diperlukan untuk menyempernukan karangan narasi misalnya penggunaan kalimat efektif, penggunaan diksi, penerapan ejaan dan penggunaan tanda baca yang tepat.

Kemampuan menulis karangan narasi setiap siswa beragam. Hal ini sesuai dengan tingkat inteletual dan kecerdasan masing-masing individu. Untuk mengembangkan kemampuan menulias karangan narasi diperlukan bantuan guru. Guru perlu membimbing secara intensif dengan memberikan motivasi kepada siswa. Motivasi belajar yang tinggi menjadi salah satu faktor yang mendukung berbagai keberhasilan siswa. Berbanding terbalik jika motivasi belajar siswa yang rendah maka berpengaruh terhadap taraf pemahaman siswa dalam menulis karangan narasi. Pemahaman kosakata berdampak pada kualitas karangan yang dibuat siswa. Dengan adanya motivasi, mendukung siswa berkeinginan untuk berkembang dan berusaha mengembangkan karangan narasi dan berbagai karyakarya yang lainnya. 
Pemahaman dan penguasaan kosakata berhubungan erat dengan kemampuan menulis. Kualitas karangan narasi yang dibuat siswa dipengaruhi oleh kepiawaian siswa dalam menyusun dan menggunakan kosakata yang efektif. Salah satu indikator siswa menguasai kosakata yakni mereka mampu memahami makna kata yang terkandung dan penggunaan dalam konteks yang tepat. Di sini peran guru sangatlah penting terutama dalam mengarahkan dan memerhatikan cara siswa dalam mengembangkan ide-ide yang kemudian dituangkan melalui karangan narasi. Hal ini dilakukan sebagai bentuk untuk meminimalkan tingkat kekeliruan dalam menyajikan karangan narasi sehingga tujuan yang diharapkan penulis selaras dengan maksud dan tujuan yang diharapkan.

Untuk membuat karangan narasi yang baik, siswa harus dapat berpikir kreatif, memiliki ide yang tepat, dan daya imajinasi yang tinggi. Oleh karena itu, dibutuhkan penguasaan kosakata dan motivasi belajar yang tinggi. Proses penguasaan kosakata dan motivasi yang tinggi mendorong siswa untuk menuliskan ide-ide, pengalaman, dan pemhamannya ke dalam karangan narasi yang sesuai dengan kualitas yang optimal.

Berdasarkan paparan di atas, terdapat beberapa faktor yang memengaruhi kemampuan menulis karangan narasi. Masalah penguasaan kosakata dan motivasi belajar bahasa Indonesia membuat karangan narasi siswa menjadi berkualitas. Masalah ini cukup menarik untuk diteliti lebih lanjut, sehingga peneliti mencoba meramunya lebih sistematis. Adapun judul penelitian ini adalah Pengaruh Penguasaan Kosakata dan Motivasi Belajar Terhadap Kemampuan Menulis Karangan Narasi bahasa Indonesia (survey terhadap Siswa Kelas VIII SMP Negeri se-Kecamatan Tirtajaya Kabupaten Karawang).

\section{METODE}

Penelitian menggunakan desain penelitian deskriptif kuantitatif dan dilaksanakan di kabupaten Karawang dengan populasi 1081 dan sampel yang digunakan sebanyak $10 \%$ dari banyaknya populasi yakni sebesar 108 orang siswa yang terdiri dari tiga sekolah menengah pertama (SMP Negeri 1 Tirtajaya, SMP Negeri 2 Tirtajaya, dan SMP Negeri 3 Tirtajaya).

Variabel dalam penelitian ini berjumlah tiga buah, yakni kemampuan menulis karangan narasi yang merupakan variabel terikat (Y). variabel bebasnya, yakni penguasaan kosakata $\left(\mathrm{X}_{1}\right)$ dan motivasi belajar $\left(\mathrm{X}_{2}\right)$. Instrumen yang digunakan dalam penelitian ini adalah: (1) tes kemampuan menulis karangan narasi berdasarkan soal yang telah disediakan dengan butir penilaian yang sudah dirancang, (2) tes penguasaan kosakata dan (3) pengukuran motivasi belajar. Untuk tes bebas (penguasaan kosakata) menggunakan sistem penilaian (scoring) dikotomis, yaitu 0 untuk jawaban salah, dan nilai 1 untuk jawaban benar. Sistem penilaian ini juga berlaku untuk variabel bebas motivasi belajar. Sedangkan untuk kemampuan menulis karangan narasi, data yang digunakan nondikotomis.

analisis deskriptif akan dilakukan teknik penyajian data dalam bentuk tabel distribusi frekkuensi, grafik poligon dan histogram untuk masing-masing variabel penelitian. Selain itu juga masing-masing kelompok data akan diolah dan dianalisis ukuran pemusatan dan letak mean, median, dan modus serta ukuran simpangan seperti jangkauan, variansi, simpangan baku, kemencengan dan 
kurtosis. Untuk perhitungan analisis deskriptif digunakan program SPSS version 20.064 bit for windows. Uji normalitas bertujuan untuk mengetahui apakah data hasil pengumpulan berdistribusi normal atau tidak. Hal ini akan berpengaruh pada proses lanjutan analisis statistik, jika data berdistribusi normal, maka analisis dilanjutkan menggunakan statistik parametrik, sedangkan jika data tidak berdistribusi normal, maka analisis dilanjutkan menggunakan statistik non parametrik. Uji normalitas dapat dilakukan menggunakan analisis Kolmogorov Smirnov dalam SPSS statistik v20-32bit. Distribusi data dikatakan normal jika nilai sig KS $>0,05$. Pengujian linieritas garis regresi dalam penelitian ini digunakan Uji F. Dalam prakteknya, akan digunakan bantuan program SPSS statistik v20-32bit untuk menghitung uji linieritas, yaitu dengan melihat besarnya nilai koefisien sig pada Deviation from Liniearity. Untuk mengetehui terjadi kolinearitas atau multikoloniearitas diantara variabel bebas dalam suatu model regresi dilakukan dengan melihat atau menguji nilai VIF (variance Inflation Factor) atau nilai TOL (Tolerance). Kriteria pengujian untuk mengetahui terjadi atau tidaknya multikoloniearitas sebagai berikut "jika nilai Tol $\leq 0,1$ atau nilai VIP $\geq 10$, terima $\mathrm{H}_{0}$ atau dikatakan terjadi multikoloniearitas.

Setelah keseluruhan uji persyaratan analisis data dipenuhi dan diketahui data layak untuk diolah lebih lanjut, maka langkah berikutnya adalah menguji masing-masing hipotesis yang telah diajukan. Pengujian hipotesis menggunakan teknik korelasi partial dan korelasi ganda, serta regresi linier sederhana dan regresi linier ganda. Dalam praktiknya, untuk perhitungan dan pengujian korelasi dan regresi baik partial maupun ganda akan digunakan bantuan program SPSS statistik v20-32bit.

\section{HASIL DAN PEMBAHASAN}

Penelitian ini bertujuan untuk mengetahui pengaruh Penguasaan kosakata dan Motivasi belajar terhadap Kemampuan Menulis Karangan Narasi bahasa Indonesia.

Dari deskripsi data setelah dilakukan analisis korelasi diperoleh koefisien korelasi sebesar 0,365 setelah dilakukan pengujian dengan program SPSS terbukti bahwa koefisien korelasi tersebut signifikan. Hal ini berarti bahwa terdapat pengaruh variabel bebas X1 (Penguasaan kosakata) dan X2 (Motivasi belajar) secara bersama-sama terhadap variabel terikat Y (Kemampuan Menulis Karangan Narasi bahasa Indonesia).

Dari analisis regresi diperoleh persamaan garis regresi $\widehat{Y}=106,901+$ 0,163 X1 - 0,427 X2. Nilai konstanta $=106,901$ menunjukkan bahwa Siswa dengan Penguasaan kosakata dan Motivasi belajar paling rendah sulit untuk bisa meraih Kemampuan Menulis Karangan Narasi bahasa Indonesia yang baik, sedangkan nilai koefisien regresi sebesar 0,163 dan 0,427 menunjukkan bahwa terdapat pengaruh positif variabel bebas X1 (Penguasaan kosakata) dan X2 (Motivasi belajar) secara bersama-sama terhadap variabel terikat Y (Kemampuan Menulis Karangan Narasi bahasa Indonesia). Setelah dilakukan pengujian linieritas garis regresi dengan menggunakan program SPSS diperoleh bahwa garis regresi tersebut linier. 
Dari pengujian signifikansi koefisien regresi yang juga dilakukan dengan program SPSS diperoleh bahwa koefisien regresi tersebut signifikan, yaitu ditunjukkan oleh nilai Sig $=0,001$ dan Fhitung $=8,089$ sehingga nilai Sig $<0,05$ atau regresi tersebut signifikan, yang berarti benar bahwa terdapat pengaruh yang positif variabel bebas X1 (Penguasaan kosakata) dan X2 (Motivasi belajar) secara bersama-sama terhadap variabel terikat Y (Kemampuan Menulis Karangan Narasi bahasa Indonesia).

Kemampuan menulis narasi adalah salah satu kemampuan berbahasa dalam pelajaran bahasa Indonesia yang ditunjukkan peserta didik setelah mengalami proses pembelajaran dalam kurun waktu tertent yang diukur melalui evaluasi. Senada dengan pendapat tersebut, Akhadiah (1991: 143) mengatakan bahwa,'kemampuan menulis bukanlah kemampuan yang diwariskan secara turuntemurun, tetapi merupakan hasil proses belajar-mengajar dan kete-kunan barlatih". Jadi, kegiatan menulis terutama dikaitkan dengan kemampuan atau keterampilan tidak dating dengan sendirinya, tetapi perwujudannya melalui latihan yang sungguh-sungguh dan intensif. Dengan kata lain, belajar dan berlatih merupakan dua komponen yang wajib dilakukan untuk mencapai kemampuan menulis.

Berdasarkan pendapat-pandapat di atas, maka yang dimaksud dengan kemampuan dalam penelitian ini menurut hemat penulis adalah kecakapan atau daya yang dilalui oleh seorang mahasiswa sebagai hasil pembelajaran terutama pembelajaran bahasa. Dengan demikian, manusia pada dasarnya memiliki dua kemampuan berbahasa, yaitu kemampuan yang bersifat reseptif dan kemampuan yang bersifat produktif. Kemampuan berbahasa yang disebut pertama mengacu pada kemampuan manusia untuk menyerap dan memahami berbagai informasi dengan cara reseptif ini dapat dilakukan melalui kegiatan membaca dan aktif menyimak, sedangkan kemampuan yang kedua berhubungan dengan kemampuan manusia dalam menggunakan bahasa untuk mengaktualisasikan dirinya baik melalui kegiatan berbicara maupun kegiatan menulis. menurut Gie (2002: 7) "Karangan adalah hasil dari segenap rangkaian kegiatan seseorang dalam mengungkapkan buah pikirannya melalui bahasa tulis untuk dibaca dan dimengerti oleh orang lain".

Penguasaan kosakata dapat dibedakan pula menjadi penguasaan aktifproduktif dan pasif-reseptif (Soenardi, 1996: 43). Berdasarkan pengertian tersebut dapat disimpulkan bahwa kegiatan berbahasa, baik menyimak, berbicara, membaca, maupun menulis sangat memerlukan penguasaan kosakata dengan baik. Kemampuan seseorang dalam berbahasa dapat dilihat dari penguasaan kosakata yang dimiliki. Seseorang dalam mengembangkan kemampuannya menulis karangan narasi dipengaruhi oleh motivasi. Kemauan yang tinggi akan mampu mengalhkan segala ketidakjelasan dalam pemikiran. Motivasi mampu memberikan semnagat yang tinggi kepada seseorang. Motivasi dalam perkembangannya dibagi menjad dua yaitu motivasi intrinsik dan motivasi ekstrinsik (Martini Yamin, 2007: 226). Motivasi intrinsik diartikan dengan motivasi yang bersumber dari dalam diri seseorang yang atas dasarnya kesadaran sendiri untuk melakukan sesuatu pekerjaan belajar. Motivasi ekstrinsik diartikan 
dengan motivasi yang datangnya dari luar diri seseorang yang menyebabkan peserta didik tersebut melakukan kegiatan belajar.

Berdasarkan informasi kauntitaif yang diperoleh dari hasil analisis deskriptif dan didukung oleh teori-teori yang ada peneliti dapat menyimpulkan bahwa penguasaan kosakata dan motivasi belajar berpengaruh positif dan signifikan secara bersama-sama terhadap kemampuan menulis karangan narasi bahasa Indonesia.

Dari pengujian hipotesis diperoleh bahwa nilai Sig $=0,020$ dan thitung $=$ 2,359, nilai Sig < 0,05 maka H0 di tolak yang berarti terdapat pengaruh yang signifikan variabel bebas X1 (Penguasaan kosakata) terhadap variabel terikat Y (Kemampuan Menulis Karangan Narasi bahasa Indonesia).

Menurut sintesis teori berkaitan dengan keterampilan menulis ekspresif Britton dalam Collins dan Parkhurst (1996: 279) mengatakan bahwa penulisan ekspresif adalah suatu jembatan yang sempurna untuk membuat dua kategori tentang penulisan-penulisan tanggapan dan penulisan puisi, karena model penulisan tersebut paling banyak digunakan para kalangan siswa.Di sini penulisan tanggapan diartikan penulisan ilmiah dan penulisan puisi dikategorikan penulisan karya sastra.

Buku dengan judul Penganjar Pemahaman Bahasa Manusia oleh Soejono (2003) mengungkapkan temuan bahwa anak usia lima tahun sudah bisa menguasai nomina lebih banyak daripada verba, setelah itu adjektiva, dan kata fungsi di urutan keempat. Pemahaman kosakata pada anak tergantung pada lingkungan si anak beradaptasi, dan sesuai dengan tingkatan umurnya. Terhadap pemahaman kosakata, bila sering diucapkan dan didengar si anak, akan mudah dan cepat dipahami. Buku tersebut menambah wawasan dan padat dipakai acuan untuk mendapatkan konsep atau teori.

Untuk dapat menyampaikan gagasan dan ide kepada orang lain melalui tulisan seorang penulis haruslah terampil memanfaatkan grafologi, struktur bahasa, dan kosakata, sebab penguasaan kosakata sangat dibutuhkan dalam kegiatan menulis untuk melahirkan sebuah tulisan atau karya sastra. Menulis erat kaitannya dengan proses menerjemahkan ide menjadi simbol atau lambang bahasa. Menurut M. Atar Semi (2007: 14) menulis adalah suatu proses kreatif memindahkan gagasan ke dalam lambang-lambang tulisan. Pendapat serupa dikemukakan oleh Nurdin (2007: 4) bahwa menulis adalah serangkaian kegiatan seseorang dalam rangka mengungkapkan gagasan dan menyampaikannya melalui bahasa tulis kepada orang lain agar mudah dipahami . Menulis kegiatan produktif dan ekspresif salah satunya adalah menulis karya fiktif maupun nonfiktif.

Dengan kata-kata seseorang dapat berpikir, berpendapat, meluapkan perasaanya, idenya, dan gagasan. Penguasaan kosakata sangat memengaruhi pemahaman atas suatu bacaan. Apalagi jika dihubungkan dengan kegiatan seharihari, seseorang yang memiliki banyak kosakata akan mampu berkomunikasi dengan baik dengan anggota masyarakat lain. Adanya komunikasi dua arah sehingga tujuan dari komunikasi tersebut tersampaikan dengan jelas.

Berdasarkan informasi kuantitatif tersebut dan didukung oleh teori-teori yang ada maka dapat disampaikan bahwa penguasaan kosakata memiliki pengaruh 
yang positif dan signifikan terhadap kemampuan menulis karangan narasi bahasa Indonesia.

Dari pengujian hipotesis diperoleh bahwa nilai Sig $=0,004$ dan thitung $=$ 2,943, karena nilai Sig < 0,05, maka H0 di tolak yang berarti terdapat pengaruh yang signifikan variabel bebas X2 (Motivasi belajar) terhadap variabel terikat $\mathrm{Y}$ (Kemampuan Menulis Karangan Narasi bahasa Indonesia).

Motivasi dapat diartikan sebagai kekuatan (energi) seseorang yang dapat menimbulkan tingkat persistensi dan antusiasmenya dalam melaksanakan suatu kegiatan, baik yang bersumber daridalam diri individu itu sendiri (motivasi intrinsik) maupun dari luar individu (motivadi ekstrinsik). Menurut Hamalik (2001 : 27-28), belajar adalah suatu proses perubahan tingkah laku melalui interaksi dengan lingkungannya. Dalam kegiatan belajar mengajar, motivasi dapat dikatakan sebagai daya penggerak di dalam diri seseorang peserta didik untuk menimbulkan kegiatan belajar dan menjamin kelangsungan kegiatan belajar, sehingga tujuan yang dihendaki oleh subjek belajar itu dapat tercapai.

Menurut Nasution (1995: 73) motivasi adalah segala daya yang mendorong seseorang untuk melakukan sesuatu.

Belajar merupakan suatu proses yang meliputi berbagai kompetensi dari berbagai pengetahuan yang mudah dan sederhana hingga kepada keterampilan yang membutuhkan kemampuan yang kompleks serta melibatkan berbagai prosedur yang memiliki tingkat kesulitnn yang tinggi. Dalam dunia pendidikan, belajar merupakan inti dari kegiatan pendidikan. Oleh karena itu, kegiatan belajar harus ditata dengan baik oleh instansi pendidikan, karena kegagalan dalam mengelola kegiatan belajar berarti tidak terwujud pula tujuan pendidikan.

Berhubungan dengan pembelajaran menulis karangan narasi, motivasi sangat berpengaruh terhadap kemampuan dan kemauan seseorang dalam mengembangkan keterampilannya dalam mengungkapkan ide atau gagasan. Sesorang yang sering berlatih akan jauh berbeda dengan seseorang yang belum terbiasa berlatih. kemampuan menulis karangan narasi perlu dilatih. rasa ingein berlatih tersebut memerlukan motivasi baik yang bersummber dari luar maupun motivasi yang bersumber dari dalam jiwa seseorang.

Penguasaan kosakata dan motivasi memengaruhi tingkat kemampuan seseorang dalam menulis karangan narasi. Tingginya prestasi seseorang dalam membuat karangan narasi tentunya tidak terlepas dari penguasaan kosakata dan motivasi yang tinggi pula dalam dirinya.

Berdasarkan informasi kuantitatif tersebut dan didukung oleh teori-teori yang ada maka dapat disampaikan bahwa motivasi belajar memiliki pengaruh yang positif dan signifikan terhadap kemampuan menulis karangan narasi bahasa Indonesia.

\section{SIMPULAN}

Kemampuan menulis karangan narasi Bahasa Indonesia siswa kelas VIII Negeri se-kecamatan Tirtajaya Kabupaten Karawang yang diteliti melalui metode survei dipengaruhi oleh dua variabel, yaitu penguasaan kosakata dan motivasi belajar siswa. Penguasaan kosakata berperan dalam kemampuan yang dimiliki 
siswa untuk membuat karangan narasi. Semakin banyak kosakata yang dimiliki siswa semakin lengkap pula gagasan-gagasan dalam bentuk kalimat yang kemudian dijadikan karangan narasi. Selanjutnya, Kemampuan siswa dalam menulis karangan narasi pula dipengaruhi oleh motivasi belajar. Rendahnya motivasi belajar, berpenagruh pada kemampuan siswa dalam menulis karangan narasi. Tetapi sebaliknya, semakin tinggi motivasi belajar, keinginan siswa untuk menulis karangan narasi semakin tinggi pula.

\section{DAFTAR PUSTAKA}

Akhadiah, S. (1995). Pembinaan menulis bahasa Indonesia. Jakarta: Erlangga.

Alwi, H. (2007). Kamus besar bahasa indonesia edisi ketiga. Jakarta: Balai Pustaka.

Gie, L. (1995). Pengantar dunia karang-mengarang. Yogyakarta: Liberty.

Keraf, G. (2005c). Komposisi. Ende Flores: Nusa Indah.

Kosasi, A., Waluyo, J.H., \& Sunardi. (ed) (2004, September) Pengaruh media gambar terhadap kepribadian siswa pada pendidikan budi pekerti.jurnal penelitian teknologi pendidikan volume 2 nomor hlm. 28-53.

Kridalaksana, H. (2009). Kamus linguistik: edisi keempat.Jakarta: Gramedia.

Lamuddin, F. (2008). Komposisi bahasa Indonesia. Jakarta: Diksi Intan Mulia.

Musrifah, N. (1999). Analisis kesalahan sintaksis pada karangan siswa kelas III SLTP Negeri 13 Yogyakarta Tahun Pelajaran 1998-1999. Yogyakarta: IKIP Yogyakarta.

Nasution. (1995a). Didaktik asas-asas mengajar. Bandung: Jenmars.

Nasution. (2002b). Didaktik asas-asas mengajar. Bandung: Jenmars.

Soenardi. (1996). Tes Bahasa dalam pengajaran. Bandung: Ensiklopedia.

Sudiana, I. N. (2007.) Retorika: bertutur efektif. Sidoarjo: Asri Press.

Yamin, M. (2007). Kiat membelajarkan siswa. Jakarta: Gaung Persada. 